\title{
Turkish Fathers' Language Use In The Context Of Toy Play $^{92}$
}

\author{
Ozge Cengiz, Assist. Prof. \\ İstanbul Medeniyet University, Turkey \\ Hamide Cakir, Assist. Prof.
}

Nigde University, Turkey

doi: 10.19044/esj.2016.v12n8p430 URL:http://dx.doi.org/10.19044/esj.2016.v12n8p430

\begin{abstract}
Parent-child interactions and the characteristics of child-directed language have been related to children's linguistic development. Studies on parent-child interactions have generally focused on mothers. There has been very little research on the language used by fathers in interactions with their children. This study addresses this gap by investigating the properties of Turkish paternal language use including their use of question types within the framework of Bloom's Taxonomy of Cognitive Domain; that is, we try to explore to what extent fathers' language use differentiates depending on their socioeconomic status in terms of Bloom's Taxonomy, thus which fathers help their children gain higher thinking skills before entering school. Bloom's Taxonomy which is a model of classifying thinking according to six cognitive levels of complexity (remember, understand, apply, analyze, evaluate, create) is hierarchical; in that, each level is subsumed by the higher levels. In this cross-sectional study, high and low socioeconomic status (SES) fathers were taped in their homes with their preschoolers in the context of toy play. The results showed that both group of fathers produced the most utterances at the remember level. Both groups produced no utterance at the analyze level, and low SES fathers produced no utterance at the apply and create levels. High SES fathers asked open ended question at all levels except the analyze level, while low SES fathers asked open ended questions only at the remember and understand levels.
\end{abstract}

Keywords: Paternal language, Bloom's Taxonomy of Cognitive Domain, Child language development, Father-child interactions, open ended questions

\footnotetext{
${ }^{92}$ This article is a revised and extended version of the paper presented at the International Symposium on Language and Communication.
} 


\section{Introduction}

Linguistic development starts with the communication at home. Parents' socioeconomic status (SES) plays a very important role in children's language development (Hoff, 2003). According to Hoff, Laursen \& Tardif (2002), mothers' talk to children differs as a function of SES; high SES mothers show more of the characteristics of maternal speech that are positively associated with language development than lower SES mothers. McCabe \& Peterson (1991) and Peterson \& McCabe (1992) also claim that differences in parental style of talking with young children affect children's later narrative style. Most of the research on parent-child interactions has focused on mothers, and not fathers. However, over the last few decades there has been growing interest in research on fathers, and studies have shown that fathers' engagement with their children is related to children's linguistic and cognitive development. Interactions between fathers and their young children are also predictive of positive child cognitive and language outcomes (Tamis-LeMonda, Shannon, Cabrera \& Lamb, 2004; Duursma, Pan \& Raikes, 2008; Pancsofar \& Vernon-Feagans, 2006; 2010).

In Turkey, although there are studies concerning fathers' attitude towards childcare, perceptions of their fathering roles and their participation levels in child care (e.g. Bekman, 2001; Fişek, 2001; Taşkın \& Erkan, 2009), there is almost no research to our knowledge on the properties of paternal language use compared to the number of studies in other countries. Thus, this cross sectional study focuses on the link between fathers' SES and their language use during the preschool period. While previous studies on parentchild interaction investigated language input in contexts such as bookreading, picture reading, meal time and dressing (Hoff-Ginsberg, 1991; Bus, van Ijzendoorn \& Pellegrini, 1995; Reese \& Cox, 1999; Ekmekçi \& Keşli, 2001; Zevenbergen \& Whitehurst, 2003; Küntay \& Ahtam, 2004; Türkay, 2007; Cengiz, 2010, 2013; Cengiz \& Çakır, 2012, 2015), this study aims to investigate the properties of paternal language use by examining the interaction between fathers and their preschoolers in the context of toy play with regard to Bloom's Taxonomy of Cognitive Domain.

\section{Theoretical Background}

Bloom's Taxonomy of Educational Objectives is a framework for classifying statements of what students are expected to learn as a result of instruction. Bloom, for whom the levels of cognitive domain mean thinking skills, identified six levels in a hierarchical framework, from simple to more complex and from concrete to abstract; achievement of the next more complex skill or ability required achievement of the prior one (Krathwohl, 2002). The taxonomy is a model of classifying thinking hierarchically according to six levels of complexity; that is, each level is subsumed by the 
higher levels (Forehand, 2005). Thus, it is a means of facilitating the exchange of test items among members of various universities in order to create banks of items, each measuring the same educational objective (Krathwohl, 2002). In other words, it was developed as a means to classify the goals of the educational system. In Bloom's own words, "its purpose was to improve the exchange of ideas and materials among test workers and other persons concerned with educational research and curriculum development" (Bloom, 1956). It was published in 1956, became widely known and later it was translated into 22 languages. It is still widely used in educational research (Davidson \& Baldwin, 2005).

During the 1990's, Anderson, a former student of Bloom's, led a new assembly in order to update the taxonomy and the revision was published in 2001 with some changes in terminology which are shown in Figure 1 below:

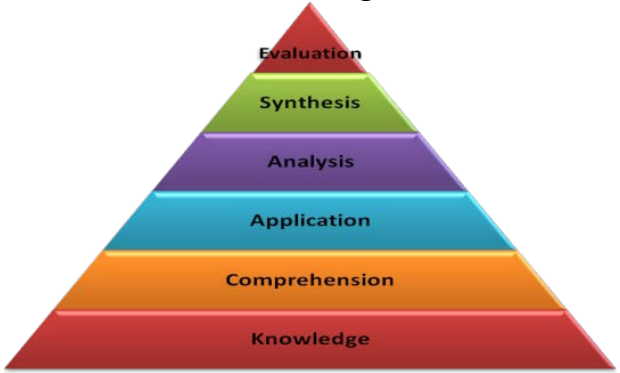

Old Version

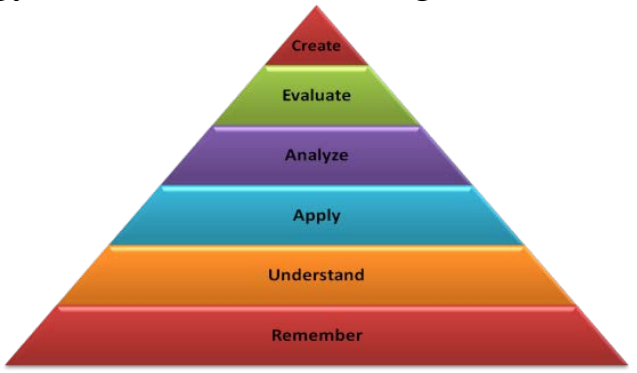

New Version

Figure 1. Bloom's Taxonomy: Old Version and New Version (Anderson \& Krathwohl, 2001)

The main difference between the two versions is that six major levels were changed from noun to verb forms. Another difference is that synthesis and evaluation levels in the original version have been reversed as evaluate and create. Therefore, the levels of the revised taxonomy are remember, understand, apply, analyze, evaluate, create. Each level consists of a verb that represents a cognitive process and a noun that describes the knowledge expected. No one level is better than another, they all serve a purpose depending on the situation, but our ultimate goal must be to get to the higher levels. According to Fisher (2006), while telling a story, the following typical questions might be asked:

- Remember: What happened in the story?

- Understand: Why did it happen that way?

- Apply: What would you have done?

- Analyze: Which part did you like best?

- Evaluate: What do you think of the story and why?

- Create: Can you think of a different ending? 
Children are faced with many challenges when they enter school. Children at the age of four in the Netherlands, for example, make a transition from informal home setting to the formal context of school (Laghzaoui, 2011). They are also expected to deal with a new language register which differs from the input that their parents provide at home. It is labeled academic language and is cognitively high demanding like the higher levels of Bloom's Taxonomy. Home environment is the first place where children are exposed to language input. Biemiller (2005) argues that when children are at age five, it is home, that is, the parents who determine language development. Thus, the characteristics of child-directed language are crucial in linguistic development. However, the pattern of interaction between parents and their children and the language input that the parents provide may differ among families. Family SES is one of the variables that causes this difference. Several studies have found links between SES and early language development (Fish \& Pinkerman, 2003; Hart \& Risley; 1995). Hoff-Ginsberg (1998) found that high SES families used richer vocabulary of object labels. Heath (1983) and Ninio (1980) also indicated that parents from low SES talk much less to their children than high SES parents.

At the heart of this present paper is the analysis of the diversity of father speech, and an examination of the relation between their SES and language use while interacting with their children playing with toys. Within the framework outlined so far, the following research question guided this study:

- What kind of, if any, SES-related differences are found between fathers' language use including types of their questions in the context of toy play with regard to Bloom's Taxonomy of Cognitive Domain?

\section{Methodology \\ Participants}

Ten fathers and their five-year old children participated in this study. The reason for the small number of participants is that fathers had little or no incentive to attend, or were not available due to their working hours. Difficulties in recruitment of fathers were also caused by suspicion of a project on testing intelligence. Therefore, mothers were enlisted to encourage their partners to participate. Mothers' encouragement and information on the study helped to ensure father participation. Families participating in the research were married, with both parents living in the home. All families lived in İzmir and were native Turkish speakers. Table 1 provides demographic information on the fathers participating this study. 
Table 1. Descriptive information of fathers $(n=10)$

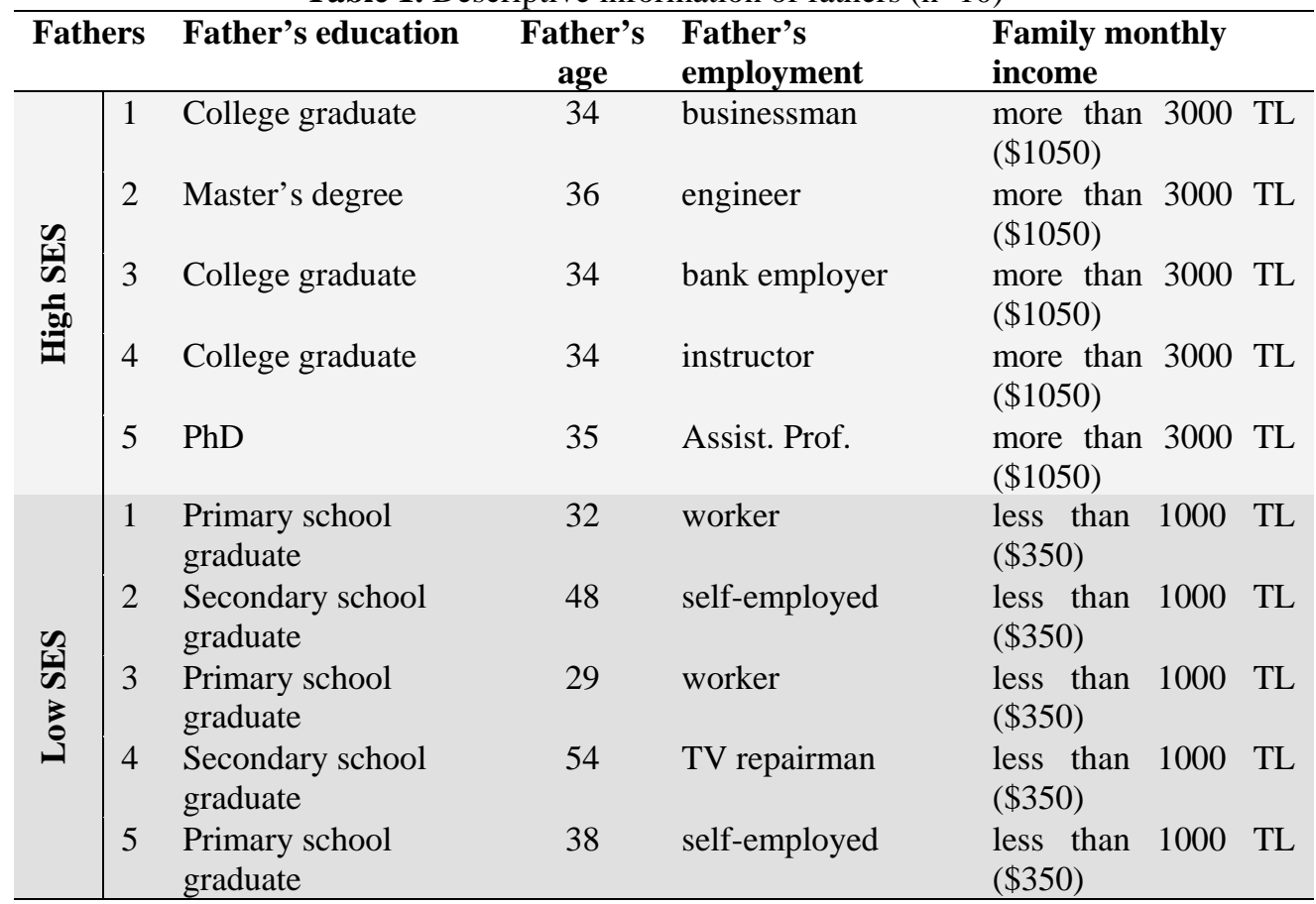

The father participants ranged in age from 29 to 54 years, with a mean of 37,4 years. The average age of high SES fathers was 34.6 and that of low SES fathers was 40.2. While low SES fathers had only a primary or secondary school education, high SES fathers had completed four years of college $(n=3)$ or received a master's $(n=1)$ or doctoral degree $(n=1)$. The fathers were employed outside of the home. Low SES fathers lived in suburban areas, whereas high SES fathers maintained an upper middle class lifestyle, and lived in more affluent districts.

\section{Procedure}

Participants were selected by means of purposive and snowball sampling methods. After obtaining fathers' consent to participate in the research, fathers were visited at home by the two researchers. Before the observational session, each father was interviewed regarding his education, age and employment. After the interview process, the father-child dyad was invited into a separate room. Fathers were instructed to play with their children for about 20 minutes the way they usually would do with the building blocks provided by the researchers. The only restriction was that they had to play in the field of the voice recorder and that they should use the toys provided. The father-child dyads sat on the floor during the play session. The researchers placed a voice recorder on the floor and were not present in 
the room during the recording in order to make the father-child dyads feel comfortable. Recording started when each dyad had settled in the room, which was approximately one minute after they came into the room. If the child was distracted from playing or not willing to play in the room, they were allowed to terminate the session and leave the room. Problems in starting the play session were not observed. On the contrary, the children were very interested in the toys and wanted to play with their fathers.

As illustrated in Figure 2, the toys used in this context were building blocks with a track set. The blocks had different colors and shapes and contained a little bell, ramps and glass marbles.

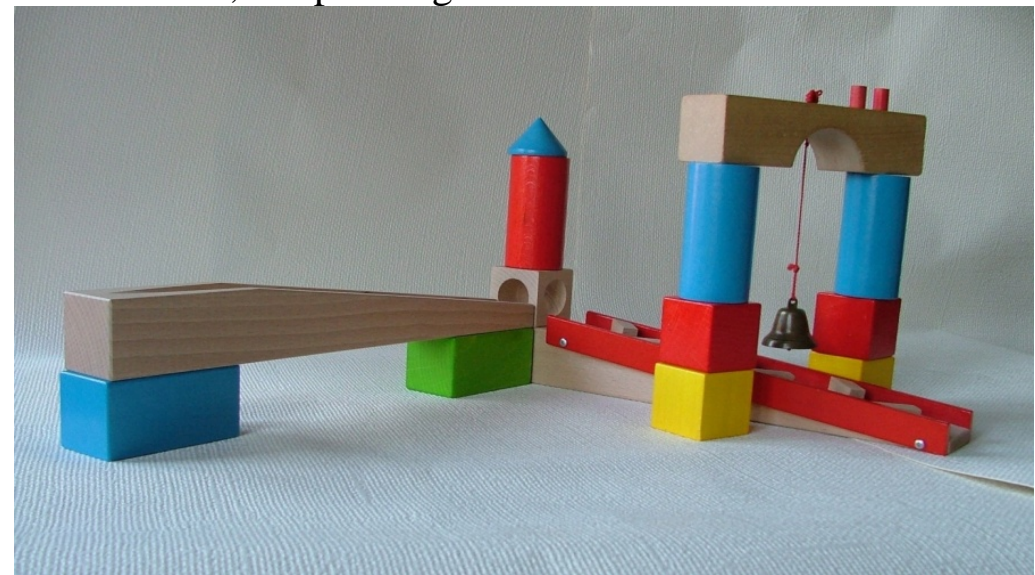

Figure 2. Toy Blocks

The picture above was shown to the father-child dyads and they were told to use the blocks to build what they saw in the picture or that they were free to construct whatever they wanted.

\section{Transcription of speech}

All fathers and their five-year old children showed an interest in the interactive toy play session. Each interaction lasted between 06:00 and 36:00 minutes $(M=15: 00 \mathrm{~min}$.$) . These interactions were taped and then$ transcribed. The fathers flow of speech was divided into utterances. An utterance is a conversational turn that contains one or more syntactic units (e.g. blue, square block, under the bell, the marble is going down the ramp) and it is usually preceded and followed by a pause (Huttenlocher et al., 2010). Two or more independent clauses occurring within the same conversational turn were considered as separate utterances.

\section{Analysis of speech}

Transcripts were analyzed and fathers' utterances were ascribed to the corresponding level of Bloom's Taxonomy of Cognitive Domain using 
the revised taxonomy. Thus, each utterance was classified into one of the six cognitive levels.

A reliability measure was applied; both researchers coded the utterances separately and verified their results by comparing the codes for each utterance. Reliability was at least 95\%, and conflicts were resolved through comparing codes and discussing differences.

Because the total number of utterances differs for high SES and low SES fathers, the results of this analysis are presented in raw numbers and also in percentages to show the distribution of utterances between the two groups. Statistics were performed on the results to determine significance levels. Since the sample size of the study was small, a nonparametric test, two-independent-sample test, Mann Whitney U was applied using SPSS statistical packages (version 13.0). Statistical significance for all measures was deemed at $\mathrm{p}<0,10$ based on two-independent-sample test.

\section{Results}

\section{Utterances of fathers on the Cognitive Domain}

In this study, we were interested in investigating the link between fathers' SES and the language they use during the preschool period of their children with regard to Bloom's Taxonomy of Cognitive Domain.

In Table 2, the percentages and the raw numbers (in parentheses) of utterances are given. As shown in the table, both groups of fathers produced the most utterances in remember which is the lowest thinking level of Bloom's Taxonomy. 94\% of the utterances of low SES fathers and $87 \%$ of high SES fathers' were coded in this level. As for the other levels, the proportions of fathers' utterances were less than $10 \%$ at the understand and evaluate levels; at the apply and create levels only high SES fathers produced utterances, and at the analyze level none of the fathers produced any utterances.

Table 2. Overall Distribution of Fathers' Utterance Levels

\begin{tabular}{lccccccc}
\hline & Remember & Understand & Apply & Analyze & Evaluate & Create & Total \\
\hline High SES & $\mathbf{8 7 \%}$ & $\mathbf{6 \%}$ & $\mathbf{1 . 4 \%}$ & $\mathbf{0 \%}$ & $\mathbf{5 \%}$ & $\mathbf{0 . 6 \%}$ & $\mathbf{1 0 0 \%}$ \\
Fathers & $(1364)$ & $(87)$ & $(21)$ & $(0)$ & $(76)$ & $(9)$ & $(1557)$ \\
Low SES & $\mathbf{9 4 \%}$ & $\mathbf{1 . 5 \%}$ & $\mathbf{0 \%}$ & $\mathbf{0 \%}$ & $\mathbf{4 . 5 \%}$ & $\mathbf{0 \%}$ & $\mathbf{1 0 0 \%}$ \\
Fathers & $(799)$ & $(13)$ & $(0)$ & $(0)$ & $(39)$ & $(0)$ & $(851)$ \\
\hline
\end{tabular}

The total number of utterances produced by high SES versus low SES fathers in terms of Cognitive Domain is shown as a graph in Figure 3 below: 


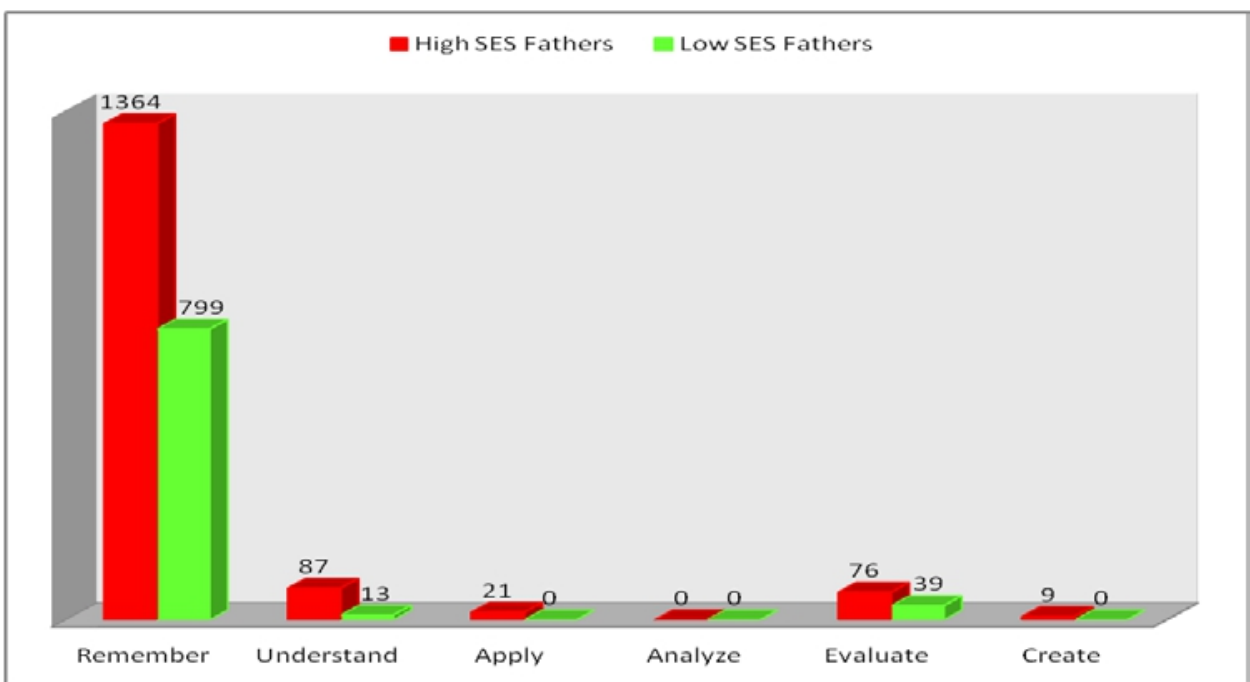

Figure 3. The total number of utterances produced by high vs. low SES fathers

The data presented in Table 2 and Figure 3 shows the percentages and the numbers of fathers' utterances as two separate groups; that is, high SES vs. low SES. Results presented in Figure 3 show that high SES fathers used a greater number of utterances in each level than low SES fathers during the father-child play session. In other words, fathers who had a higher education produced more utterances during toy play (high SES: 1557, low SES 851). Table 3 presents the statistics on the total number of utterances by the fathers.

In Table 3, the p-value is .047. Since the p-value is less than the level of significance $(0,10)$, the difference between the total number of utterances and the socioeconomic status (SES) of fathers is statistically significant ( $\mathrm{p}<$ .10).

Table 3. Test Statistics in General

\begin{tabular}{rrrl}
\hline \multicolumn{3}{c}{ Ranks } & \\
\hline & N & $\begin{array}{l}\text { Mean } \\
\text { Rank }\end{array}$ & $\begin{array}{l}\text { Sum } \\
\text { of } \\
\end{array}$ \\
& Ranks \\
\hline High & 5 & 7,40 & 37,00 \\
Low & 5 & 3,60 & 18,00 \\
Total & 10 & & \\
\hline
\end{tabular}

\begin{tabular}{lr}
\hline \multicolumn{2}{c}{ Test Statistics } \\
\hline \multicolumn{2}{c}{ VAR00001 } \\
\hline Mann-Whitney & 3,000 \\
U & \\
Wilcoxon W & 18,000 \\
Z & $-1,991$ \\
Asymp.Sig. (2- &, 047 \\
tailed) & \\
Exact Sig. &, $056^{\text {a }}$ \\
[2*(1-tailed & \\
Sig.)] & \\
\hline
\end{tabular}

a. Not corrected for ties.

b. Grouping Variable: VAR00002 
Since the sample size was small $(n=10)$ and none of the low SES fathers made any utterance at the levels of apply, analyze and create, the statistical analysis could be applied only to the levels of remember, understand and evaluate. Again, due to the smallness of the size of the sample, whether there was a difference between the number of utterances of the two groups at the levels of remember, understand and evaluation was analyzed by a nonparametric test, two-independent-sample test, Mann Whitney U analysis using SPSS statistical packages (version 13.0).

\section{Remember Level}

As can be seen in Table 4, the p-value is .249. Since the p-value is greater than the level of significance $(0,10)$, the difference between the fathers' SES and the proportion of utterances at the remember level is statistically not significant $(\mathrm{p}>.10)$.

Table 4. Test Statistics at the Remember Level

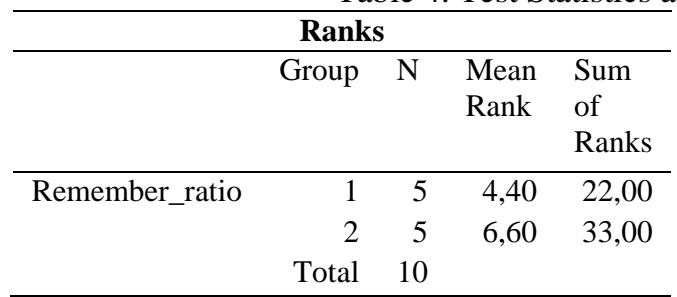

\begin{tabular}{lr}
\hline \multicolumn{2}{c}{ Test Statistics ${ }^{\mathbf{b}}$} \\
\hline \multicolumn{2}{c}{ Remember_ratio } \\
\hline Mann-Whitney & 7,000 \\
U & \\
Wilcoxon W & 22,000 \\
Z & $-1,152$ \\
Asymp.Sig. (2- &, 249 \\
tailed) & \\
Exact Sig. &, $310^{\text {a }}$ \\
[2*(1-tailed & \\
Sig.)] & \\
\hline
\end{tabular}

a. Not corrected for ties.

b. Grouping Variable: Group

\section{Understand Level}

As shown in Table 5, the p-value is .175. Since the p-value is greater than the level of significance $(0,10)$, the difference between the fathers' SES and the proportion of utterances at the understand level is statistically not significant $(p>.10)$.

Table 5. Test Statistics at the Understand Level

\begin{tabular}{rrrrl}
\hline \multicolumn{3}{c}{ Ranks } & & \\
\hline & Group & N & $\begin{array}{l}\text { Mean } \\
\text { Rank }\end{array}$ & $\begin{array}{l}\text { Sum } \\
\text { of } \\
\text { Ranks }\end{array}$ \\
\hline Understand_ratio & 1 & 5 & 6,80 & 34,00 \\
& 2 & 5 & 4,20 & 21,00 \\
& Total & 10 & & \\
\hline
\end{tabular}

\begin{tabular}{lr}
\hline \multicolumn{2}{c}{ Test Statistics } \\
\hline \multicolumn{2}{c}{ Understand_ratio $^{\mathbf{b}}$} \\
\hline Mann-Whitney U & 6,000 \\
Wilcoxon W & 21,000 \\
$\mathrm{Z}$ & $-1,358$ \\
Asymp.Sig. (2- &, 175 \\
tailed) &, $222^{\mathrm{a}}$ \\
Exact Sig. [2*(1- \\
tailed Sig.)] \\
\hline a. Not corrected for ties. \\
b. Grouping Variable: Group
\end{tabular}




\section{Evaluate Level}

As illustrated in Table 6, the p-value is .675. Since the p-value is greater than the level of significance $(0,10)$, the difference between the fathers' SES and the proportion of utterances at the evaluate level is statistically not significant $(\mathrm{p}>.10)$.

Table 6. Test Statistics at the Evaluate Level

\begin{tabular}{rrrrl}
\hline \multicolumn{5}{c}{ Ranks } \\
& Group & $\mathrm{N}$ & $\begin{array}{l}\text { Mean } \\
\text { Rank }\end{array}$ & $\begin{array}{l}\text { Sum } \\
\text { of } \\
\text { Ranks }\end{array}$ \\
\hline Evaluate_ratio & 1 & 5 & 5,90 & 29,50 \\
& 2 & 5 & 5,10 & 25,50 \\
& Total & 10 & & \\
\hline
\end{tabular}

\begin{tabular}{lr}
\hline \multicolumn{2}{c}{ Test Statistics ${ }^{\mathbf{b}}$} \\
\hline \multicolumn{2}{c}{ Evaluate_ratio } \\
\hline Mann-Whitney & 10,500 \\
U & \\
Wilcoxon W & 25,500 \\
Z &,- 419 \\
Asymp.Sig. (2- &, 675 \\
tailed) & \\
Exact Sig. &, $690^{\text {a }}$ \\
[2*(1-tailed & \\
Sig.)] & \\
\hline
\end{tabular}

a. Not corrected for ties.

b. Grouping Variable: Group

As mentioned earlier, since only high SES fathers produced utterances at the apply and create levels, statistical tests could not be applied to these levels.

\section{Fathers' use of Questions}

Fathers' utterances were analyzed in terms of question types. The findings on the total numbers of question raised by fathers are given in percentages and raw numbers in Table 7.

\section{Total number of questions}

Table 7. Overall Distribution of Fathers' Questions

\begin{tabular}{lcccc}
\hline & $\begin{array}{c}\text { Total } \\
\text { Utterances }\end{array}$ & $\begin{array}{c}\text { Total } \\
\text { Questions }\end{array}$ & $\begin{array}{c}\text { Open ended } \\
\text { Questions }\end{array}$ & $\begin{array}{c}\text { Closed ended } \\
\text { Questions }\end{array}$ \\
\hline High SES & $\mathbf{1 0 0 \%}$ & $\mathbf{2 9 . 5 \%}$ & $\mathbf{1 1 . 7 \%}$ & $\mathbf{1 7 . 8 \%}$ \\
Fathers & $(1557)$ & $(459)$ & $(183)$ & $(276)$ \\
Low SES & $\mathbf{1 0 0 \%}$ & $\mathbf{2 4 . 5 \%}$ & $\mathbf{1 2 . 8 \%}$ & $\mathbf{1 1 . 7 \%}$ \\
Fathers & $(851)$ & $(211)$ & $(109)$ & $(102)$ \\
\hline
\end{tabular}

As shown in Table 7, high SES fathers raised 459 questions (29.5\%) and low SES fathers asked 211 (24.5\%) questions during the toy play session. With the ratio of $17.8 \%$, high SES fathers asked more closed ended questions than open ended questions (11.7\%). Among low SES fathers, the rate was $12.8 \%$ in open ended questions and $11.7 \%$ in closed ended questions. Descriptive statistics on the use of question types is given in Table 8. 
Table 8. Test Statistics on Open ended Questions

\begin{tabular}{rrrrl}
\hline \multicolumn{4}{c}{ Ranks } & \\
\hline & Group & N & $\begin{array}{l}\text { Mean } \\
\text { Rank }\end{array}$ & $\begin{array}{l}\text { Sum } \\
\text { of } \\
\text { Ranks }\end{array}$ \\
\hline Evaluate_ratio & 1 & 5 & 4,40 & 22,00 \\
& 2 & 5 & 6,60 & 33,00 \\
& Total & 10 & & \\
\hline
\end{tabular}

\begin{tabular}{lr}
\hline \multicolumn{2}{c}{ Test Statistics } \\
\hline \multicolumn{2}{c}{ Evaluate_ratio } \\
\hline Mann-Whitney & 7,000 \\
U & \\
Wilcoxon W & 22,000 \\
Z & $-1,149$ \\
Asymp.Sig. (2- &, 251 \\
tailed) & \\
Exact Sig. &, $310^{\mathrm{a}}$ \\
[2*(1-tailed & \\
Sig.)] & \\
\hline
\end{tabular}

a. Not corrected for ties.

b. Grouping Variable: Group

The p-value is .251 and the p-value is greater than the level of significance $(0,10)$. Thus, the difference between the fathers' SES and the use of questions is statistically not significant $(p>.10)$. Table 9 illustrates the distribution of questions on Bloom's Taxonomy.

Table 9. Overall Distribution of Fathers' use of Questions on the Cognitive Domain

\begin{tabular}{|c|c|c|c|c|c|c|c|c|c|c|c|c|}
\hline & \multicolumn{2}{|c|}{ Remember } & \multicolumn{2}{|c|}{ Understand } & \multicolumn{2}{|c|}{ Apply } & \multicolumn{2}{|c|}{ Analyze } & \multicolumn{2}{|c|}{ Evaluate } & \multicolumn{2}{|c|}{ Create } \\
\hline & OQ & CQ & OQ & $\mathbf{C Q}$ & OQ & CQ & $\begin{array}{l}\mathbf{O} \\
\mathbf{Q}\end{array}$ & $\begin{array}{l}\mathbf{C} \\
\mathbf{Q}\end{array}$ & OQ & CQ & OQ & CQ \\
\hline High & $\begin{array}{l}8.5 \\
\end{array}$ & 14.6 & 2.7 & 0.90 & 0.26 & 0.38 & 0 & 0 & 0.12 & 1.67 & 0.12 & 0.12 \\
\hline SES & $\%$ & $\%$ & $\%$ & $\%$ & $\%$ & $\%$ & & & $\%$ & $\%$ & $\%$ & $\%$ \\
\hline $\begin{array}{l}\text { Fathe } \\
\text { rs }\end{array}$ & 132 & 228 & 43 & 14 & 4 & 6 & & & 2 & 26 & 2 & 2 \\
\hline Low & 11.6 & 10.2 & 1.17 & 0 & 0 & 0 & 0 & 0 & 0 & 1.76 & 0 & 0 \\
\hline SES & $\%$ & $\%$ & $\%$ & & & & & & & $\%$ & & \\
\hline $\begin{array}{l}\text { Fathe } \\
\text { rs }\end{array}$ & 99 & 87 & 10 & & & & & & & 15 & & \\
\hline
\end{tabular}

As seen in Table 8, while there is no significance in the total number of questions, there is an important difference in the distribution of questions on Bloom's Taxonomy. Table 9 shows that while high SES fathers asked open ended question on all levels except the analyze level, low SES fathers asked open ended questions only at the remember and understand levels. Thus, these findings suggest that high SES fathers tried to encourage their children more to think at the higher levels. In other words, high SES fathers asked open ended question on different levels on the Taxonomy, but low SES fathers asked more remember level questions.

\section{Questions at the Remember Level}

The results of the questions at the remember level are shown in Table 10. 
Table 10. Test Statistics on Open ended Questions

\begin{tabular}{rrrrl}
\hline \multicolumn{4}{c}{ Ranks } & \\
\hline & Group & N & $\begin{array}{l}\text { Mean } \\
\text { Rank }\end{array}$ & $\begin{array}{l}\text { Sum } \\
\text { of } \\
\text { Ranks }\end{array}$ \\
\hline Evaluate_ratio & 1 & 5 & 3,80 & 19,00 \\
& 2 & 5 & 7,20 & 36,00 \\
& Total & 10 & & \\
\hline
\end{tabular}

\begin{tabular}{lr}
\hline \multicolumn{2}{c}{ Test Statistics } \\
\hline \multicolumn{2}{c}{ Evaluate_ratio } \\
\hline Mann-Whitney & 4,000 \\
U & \\
Wilcoxon W & 19,000 \\
Z & $-1,776$ \\
Asymp.Sig. (2- &, 076 \\
tailed) & \\
Exact Sig. &, $095^{\mathrm{a}}$ \\
[2*(1-tailed & \\
Sig.)] & \\
\hline
\end{tabular}

a. Not corrected for ties.

b. Grouping Variable: Group

As illustrated in Table 10, no significant differences $(\mathrm{p}>.10)$ have been observed on the use of remember level questions. The statistics of understand level questions is given in Table 11.

\section{Questions at the Understand Level}

Table 11. Test Statistics on Open ended questions

\begin{tabular}{rrrrl}
\hline \multicolumn{3}{c}{ Ranks } & & \\
\hline & Group & N & $\begin{array}{l}\text { Mean } \\
\text { Rank }\end{array}$ & $\begin{array}{l}\text { Sum } \\
\text { of } \\
\text { Ranks }\end{array}$ \\
\hline Evaluate_ratio & 1 & 5 & 7,00 & 35,00 \\
& 2 & 5 & 4,00 & 20,00 \\
& Total & 10 & & \\
\hline
\end{tabular}

\begin{tabular}{lr}
\hline \multicolumn{2}{c}{ Test Statistics } \\
\hline \multicolumn{2}{c}{ Evaluate_ratio } \\
\hline Mann-Whitney & 5,000 \\
U & \\
Wilcoxon W & 20,000 \\
Z & $-1,567$ \\
Asymp.Sig. (2- &, 117 \\
tailed) & \\
Exact Sig. &, $151^{\text {a }}$ \\
[2*(1-tailed & \\
Sig.)] & \\
\hline
\end{tabular}

a. Not corrected for ties.

b. Grouping Variable: Group

The findings of questions at the understand level revealed no significant difference $(p>.10)$ between high SES and low SES fathers.

\section{Discussion}

This study examined paternal language use in terms of Bloom's Taxonomy of Cognitive Domain in the context of toy play. The major finding of the study is that in terms of the number of the utterances, high SES fathers' utterances were significantly higher than low SES fathers'. It means that high SES fathers spoke to their children much more than low SES fathers which is in accord with Heath (1983) and Ninio (1980) in that parents from low SES talk much less to their children than high SES parents. It may 
be that because high SES fathers had longer educational backgrounds and having longer educational background may raise awareness about the importance of speaking in child rearing. It may also be related with the ages of low SES fathers. Since they were older than high SES fathers, they might have felt too tired to speak much. Another important finding from the present study is that both groups of fathers produced most of the utterances at the remember level. Thus, it can be said that father-child interactions were dominated by lower-order utterances. These utterances do not allow for discussion of problem-solving strategies and mental activities necessary to respond to more higher-order thinking skills. Research on the theory of cognitive domain has revealed that excessive use of lower cognitive input may not support the development of children's critical thinking. Both groups produced no utterance at the analyze level. In addition, low SES fathers did not produce any utterance at the apply and create levels either. In these levels, high SES fathers produced utterances, but very few. As for the other three levels, that is, remember, understand and evaluation, the differences between the two groups were not significantly different. As far as the questions are concerned, an important finding is the distribution of questions on Bloom's Taxonomy. High SES fathers asked open ended question on all levels except the analyze level, whereas low SES fathers asked open ended questions only at the remember and understand levels. Thus, these findings suggest that high SES fathers tried to develop their children's higher-order thinking skills more.

Communication between young children and their parents at the preschool age is crucial with respect to children's language development along with the social, emotional and cognitive support provided. Previous research reveals that the language development of children is related to the language input to which children are exposed in early childhood in the home environment (Huttenlocher, Haight, Bryk, Seltzer \& Lyons, 1991; Tabors, Snow \& Dickinson, 2001).

Research comparing mother and father verbal input has found that fathers adopted a simplified speech register and spoke with a higher pitch (Fernald, Taeschner, Dunn \& Papousek, 1989). In their analysis of mothers' and fathers' language use, Leaper, Anderson \& Sanders (1998) found that there were no differences in the use of questions. Golinkoff \& Ames (1979) compared maternal and paternal language in a dyadic and triadic situation and found that in the dyadic situation, mothers and fathers produced similar number of utterances but in the triadic situation, the fathers made fewer utterances than mothers. There are some other studies which have not found significant differences between the two parents on measures of total output (McLaughlin, White, McDevitt \& Raskin, 1983; O’Brien \& Nagle, 1987). 
It was somewhat surprising that the low SES fathers' proportion of utterances at the evaluation level was greater than that of at the understand level compared to high SES fathers. This finding can be associated with Orlich et al.'s model of the taxonomy. Orlich et al. (1990) constructed a new interpretation of Bloom's Taxonomy of Cognitive Domain, and they went beyond the traditional display of the six major levels of the taxonomy, which assumed the steps had to be climbed one at a time. On the other hand, in Orlich et al.'s model, comprehension, that is, understanding, is the real key to unlock the entry into the other levels. Once you comprehend or truly understand a concept, then you can move into any of the other four levels -application, analysis, synthesis or evaluation (Orlich et al., 1990).

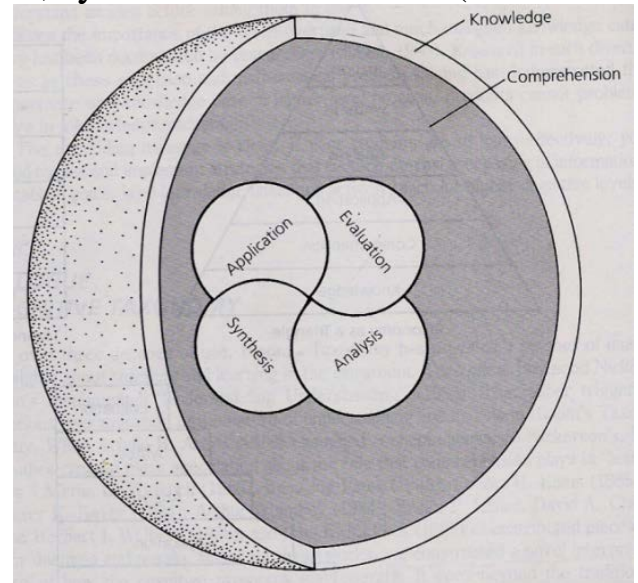

Figure 4. Interactive Model of Cognitive Taxonomy (Orlich et al., 1990:120)

Orlich et al. (1990) hypothesized that the higher levels of the cognitive taxonomy acted like an atomic nucleus (see Fig. 4). One can move rapidly from understanding to creativity, analytic thinking, evaluation or application without having to proceed one step at a time. In this respect, the findings of low SES fathers' move from understand to evaluate level and also high SES fathers' production of utterances at the evaluate and create by leaving out analyze level can be explained by Orlich et al.'s Interactive Model of Cognitive Taxonomy.

\section{Conclusion}

The purpose of the current study was to explore to what extent the paternal language use differentiates depending on SES in terms of Bloom's Taxonomy of Cognitive Domain, thus which fathers helped their children gain higher-order thinking skills before they entered school. To this extent, according to our findings, it can be said that there was not a significant difference between low SES and high SES fathers in providing their children higher-order thinking skills since fathers of both groups produced most of 
the utterances at the remember level. The reason for the high SES fathers' limited number of utterances in the higher levels can be due to children's age, in that, high SES fathers may have deliberately preferred not to produce any utterances in higher levels since they may have thought that their children were too young to understand higher-order questions. However, they aimed to raise questions almost at all levels of the taxonomy which can be accepted as an attempt to develop their children's higher-order thinking skills.

This study was limited in that the sample size $(n=10)$ was small. Another limitation was the non-homogeneity of fathers' personal characteristics. And finally, this study looked at the paternal language only within the context of toy play and in terms of Bloom's Taxonomy of Cognitive Domain. Since it was a cross-sectional study and the sample was not representative especially with regard to fathers' personal characteristics, the fathers cannot be generalized to the general population of fathers. Thus, generalization of our results requires some caution, and the limitations of the study should be borne in mind. On the other hand, this study can be regarded as having extended the existing Turkish literature on parent-child interaction and as having provided an important first step by examining paternal language use which is a domain that has received relatively little attention in Turkey. Future multidisciplinary studies are needed to investigate paternal language input in different contexts with a greater number of participants.

\section{Acknowledgements}

This report is the result of great effort on the part of many people. We start by thanking the fathers and families who agreed to let us into their homes and lives. Without their cooperation, this study would not have been possible. We would also like to thank Aslı Suner from Department of Biostatistics and Medical Informatics, Ege University. She specially made time for us from her busy schedule and provided us with the necessary statistical analysis for our investigation.

\section{References:}

Anderson, L. W. \& Krathwohl, D. R. (Eds.) (2001). A Taxonomy for Learning, Teaching, and Assessing: A Revision of Bloom's Taxonomy of Educational Objectives. New York: Longman.

Bekman, S. (2001). Çocuğun yaşamında babanın rolü ve önemi sempozyum raporu. İstanbul: Anne Çocuk Eğitim Vakfı Yayını.

Biemiller, A. (2005). Vocabulary Development and Instruction: A Prerequisite for School Learning. In: S. Neuman, \& D. Dickinson (Eds.), Handbook of Early Literacy Research (Vol. 2). New York, NY: Guilford Press. 
Bloom, B. (1956). Taxonomy of Educational Objectives. Book 1: Cognitive Domain. New York: David McKay.

Bus, A., van Ijzendoorn, M., \& Pellegrini, A. (1995). Joint book reading makes for success in learning to read: A meta-analysis on intergenerational transmission of literacy. Review of Educational Research, 65, 1-21.

Cengiz, Ö. (2010). Türk Annelerin Çocuklarına Kitap Okurken Kullandıkları Dilsel Kodlar ve Etkileşim Biçemi.(The linguistic codes and the types of verbal interactions of Turkish mothers in the context of shared book reading). Unpublished Dissertation. Dokuz Eylül University, İzmir.

Cengiz, Ö. (2013). The Language Use of Turkish Mothers in the Context of Shared Book Reading. Journal of Faculty of Letters, 30(1), 97-114.

Cengiz, Ö. \& Çakır, H. (2012a).Okulöncesi Çocuklarda Dilbilgisel Eğretileme Kullanımının Ortaya Çıkış Sürecinde Annelerinin Etkisi (The Effects of Mothers in the Emergence of Grammatical Metaphor Use in Preschoolers). Dilbilim Araştırmaları (Journal of Linguistic Research), 2012(2), 21-39.

Cengiz, Ö. \& Çakır, H. (2015). An Investigation of Maternal Input within the Framework of Bloom's Taxonomy of Cognitive Domain. In Zeyrek, D., Sagın Simsek, Ç.,Atas, U., \& Rehbein, J. (Eds.) Ankara Papers in Turkish and Turkic Linguistics (pp. 225-235). Wiesbaden: Harrassowitz Verlag. ISBN: 978-3-447-10523-1.

Davidson, R. A. \& Baldwin, B. A. (2005). Cognitive skills objectives in intermediate accounting textbooks: Evidence from end-of chapter material. Journal of Accounting Education, 23(2), 79-95.

Duursma, E. Pan, B.A. \& Raikes, H. (2008). Predictors and outcomes of low-income fathers' reading with their toddlers. Early Childhood Research Quarterly, 23, 351-365.

Ekmekçi, Ö. \& Keşli, Y. (2001). Türk Çocuklarının Anadil Edinimindeki Edimbilimsel Gelişmeleri. 15. Dilbilim Kurultayı Bildirileri (pp. 251-256). İstanbul: Yıldız Teknik Üniversitesi Yayınları.

Fernald, A., Taeschner, T., Dunn, J., \& Papousek, M. (1989). A crosslanguage study of prosodic modification in mothers' and fathers' speech to preverbal infants. Journal of Child Language, 19, 477-501.

Fişek, G. (2001). Değişik açılardan babanın çocuk gelişimindeki rolü ve önemi. Çocuğun yaşamında babanın rolü ve önemi sempozyum raporu. İstanbul: Anne Çocuk Eğitim Vakfi Yayını.

Fish, M. \& Pinkerman, B.(2003). Language skills in low-SES rural Appalachian children: Normative development and individual differences, infancy to preschool. Applied Developmental Psychology, 23, 539-565.

Fisher, R. (2006). Thinking skills. In Arthur, J., Grainger, T. \& Wray, D. (Eds.). Learning to Teach in Primary School. Routledge: Falmer. 
Forehand, M. (2005). Bloom's Taxonomy: Original and Revised. In M. Orey (Ed.), Emerging perspectives on learning, teaching, and technology. Emerging perspectives on learning, teaching, and technology. Retrieved $9^{\text {th }}$ of November 2011, from http://projects.coe.uga.edu/epltt/

Golinkoff, R. M., \& Ames, G. J. (1979). A comparison of fathers' and mothers' speech with their young children. Child Development, 50, 28-32. Hart, B. \& Risley, T. (1995). Meaningful Differences in the everyday Experience of Young American Children. Baltimore: Brookes.

Heath, S.B. (1983). Ways with words: Language, life, and work in communities and classrooms. Cambridge: Cambridge University Press.

Hoff, E. (2003). The specificity of environmental influence: Socioeconomic status affects early vocabulary development via maternal speech. Child Development, 74, 1368-78.

Hoff, E., Laursen, B. \& Tardif, T. (2002). Socioeconomic status and parenting. In M. H. Bornstein (Ed.). Handbook of Parenting (pp. 231-252). Mahwah, NJ: Erlbaum.

Hoff-Ginsberg, E. (1998). The relation of birth order and socioeconomic status to children's language development. Applied Psycholingistics, 19, 603629.

Hoff-Ginsberg, E. (1991). Mother-child conversation in different social classes and communicative settings. Child Development, 62, 782-796.

Huttenlocher, J., Haight, W., Bryk, A., Seltzer, M., \& Lyons, T. (1991). Early vocabulary growth: Relation to language input and gender. Developmental Psychology, 27(2), 236-248.

Huttenlocher, J., Waterfall, H., Vasilyeva, M., Vevea, J., \& Hedges, L.V. (2010). Sources of variability in children's language growth. Cognitive Psychology, 61, 343-365.

Krathwohl, D. R. (2002). A Revision of Bloom's Taxonomy: An Overview. Theory into Practice, 41(4), 212-218.

Küntay, A. C. \& Ahtam, B. (2004). Annelerin çocukalrıyla geçmiş hakkındaki konuşmalarının Anne eğitim düzeyiyle ilişkisi. Türk Psikoloji Dergisi, 19(54), 19-31.

Laghzaoui, M. (2011). Emergent academic language at home and at school: A longitudinal study of 3-to 6-yearold Moroccan Berber children in the Netherlands. Oisterwijk: BOXPress BV

Leaper, C., Anderson, K.J. \& Sanders, P. (1998). Moderators of gender effects on parents' talk to their children: A meta-analysis. Developmental Psychology, 34, 3-27.

McCabe, A. \& Peterson, C. (1991). Getting the story: Parental styles of narrative elicitation and developing narrative skills. In A. McCabe \& $\mathrm{C}$. Petarson (Eds.). Developing narrative structure (pp. 217-253). Hillsdale, NJ: Lawrence Erlbaum. 
McLaughlin, B. White, D., McDevitt, T., \& Raskin, R. (1983). Mothers’ and fathers' speech to their young children: Similar or different? Journal of Child Language, 10, 719-736.

Ninio, A. (1980). Ostensive definition in vocabulary learning. Journal of Child Language, 7, 565-573.

O’Brien, M., \& Nagle, K. J. (1987). Parents’ speech to toddlers: The effect of play context. Journal of Child Language, 14, 269-279.

Orlich, D. C., Harder, R. J., Callahan, R. C., Kauchak, D. P., Pendergrass, R. A., Keogh, A. J. \& Gibson, H. (1990). Teaching Strategies: A Guide to Better Instruction. Toronto: D. C. Heath and Company.

Pancsofar, N. \& Vernon-Feagans, L. (2006). Mother and father language input to young children: Contributions to later language development. Journal of Applied Developmental Psychology, 27, 571-587.

Pancsofar, N. \& Vernon-Feagans, L. (2010). Fathers’ early contributions to children's language development in families from low-income rural communities. Early Childhood Research Quarterly, 25, 450-463.

Peterson, C., \& McCabe, A. (1992). Parental styles of narrative elicitation: Effect on children's narrative structure and content. First Language, 12, 299-321.

Reese, E., \& Cox, A. (1999). Quality of adult book reading affects children's emergent literacy. Developmental Psychology, 35, 20-28.

Rowe, M. L. (2008). "Child-directed speech: Relation to socioeconomic status, knowledge of child development and child vocabulary skill”. Child Language, 35, 185-205.

Tabors, P., Snow, C., \& Dickinson, D. (2001). Homes and schools together: Supporting language and literacy development. In: D. Dickinson, \& P. Tabors (Eds.), Beginning literacy with language. Baltimore, MD: Brookes Publishing.

Tamis-LeMonda, C. S., Shannon, J.D., Cabrera, N., \& Lamb, M. (2004). Fathers and Mothers at play with their 2- and 3- year-olds. Contribution to language and cognitive development. Child Development, 75(6), 1806-1820. Taşkın, N. \& Erkan, S. (2009). Babalara verilen eğitimin babalarin çocuklariyla ilgilenmelerine etkisi: deneysel bir çalişma. Hacettepe

University Journal of Education, 37, 136-148.

Türkay, F. (2007). Türk Annelerin ad/eylem kullanımlarının Bağlam etmeniyle ilişkisi. 21. Dilbilim Kurultayı Bildirileri (pp. 273-276). Mersin: Mersin Üniversitesi Yayınları.

Zevenbergen, A. A., \& Whitehurst, G. J. (2003). Dialogic reading: A shared picture book reading intervention for preschoolers. In A.Van Kleeck, S. A. Stahl, \& E. B. Bauer (Eds.). On reading books to children: Parents and teachers. Mahwah, NJ: Lawrence Erlbaum. 